\title{
Policies on the move: Translation, assemblages and ethnography
}

Environment and Planning C: Government and Policy $0(0)$ I-4

(C) The Author(s) 2016 Reprints and permissions: sagepub.co.uk/journalsPermissions.nav DOI: $10.1177 / 0263774 \times 16663506$ epc.sagepub.com

@SAGE

Blaustein Jarrett, Speaking truths to power: Policy ethnography and police reform in Bosnia and Herzegovina. Oxford University Press: Oxford, UK, 20I5; 272 PP. ISBN 978-0-198-72329-5, $\$ 1 \mathrm{IO}$ (hbk)

Clarke John, Bainton David, Lendvai Noemi, and Stubbs Paul, Making policy move: Towards a politics of translation and assemblage. Policy Press: Bristol, UK, 20I5; 224 PP. ISBN 978-I-447-3I336-6, \$II5.00 (hbk), ISBN 978-I-447-3 I337-3, \$44.95 (pbk)

Kingfisher Catherine, A policy travelogue: Tracing welfare reform in Aotearoa/New Zealand and Canada. Berghahn Press: New York, USA and Oxford, UK, 20I3; 230 pp. ISBN 978-I-78238005-4, \$I20.00/£75.00 (hbk), ISBN 978-I-785-3322I-0, \$29.95/£I8.50 (pbk)

Peck Jamie and Theodore Nik, Fast policy: Experimental statecraft at the thresholds of neoliberalism. University of Minnesota Press: Minneapolis, USA and London, UK, 20I5; 328 PP. ISBN 978-0-8I667730-6 \$105.00 (hbk), ISBN 978-0-8I6-6773I-3 \$30.00 (pbk)

Reviewed by: Farhad Mukhtarov, Copernicus Institute of Sustainable Development, Utrecht University and Lee Kuan Yew School of Public Policy, National University of Singapore, The Netherlands

Two issues have been hotly debated in public policy in the recent years. The first is the intensive movement of policy models across space and time with often-unpredictable consequences on the ground. Nationally, policy moves from the rooms of legislators and executive officials to the offices of implementation agencies, and onto the people such policy seeks to regulate. Transnationally, it moves from one country and context to another with the help of international organizations, think tanks, independent experts, and academics (e.g. Stone, 2012). Examples of policies on the move, among many, include neo-liberal reforms in education, healthcare, and public service provision.

The second issue that increasingly gains attention is in the opening up of public policy to an ethnographic inquiry. For example, through their ethnographies, Maybin (2014) and Pachirat (2009) lift the lid on the micro-politics of policy and illustrate the human dimensions of policy-making away from the rational choice assumptions or theories of institutionalism. Instead, ethnographies allow revealing the political, cultural, traditional, emotional, ethical, and other features of complex decision-making. This is a significant methodological innovation.

Four notable new books speak to these very issues. The first book is "Speaking Truths to Power: Policy Ethnography and Police Reform in Bosnia and Herzegovina", written by Jarrett 
Blaustein. It presents an ethnography of the police reform in Bosnia and Herzegovina (BiH) assisted by the European Union, Swiss Agency for Development and Cooperation (SDC), and United Nations Development Programme (UNDP).

In introduction, Blaustein problematizes the space between "best practices" and the local police in Sarajevo as the "contact zones" (Pratt, 1992). He is interested in how transnational policy interlocutors mediate the "best practices" on the ground in Sarajevo, including the work of police officers. Blaustein authoritatively argues for the value of policy ethnography in understanding the "contact zones" of contemporary global public policy. Chapter 4 introduced the major analytical concept of the book, "policy translation", which denotes the "moving target" character of global policy models, which are "translated", rather than transferred, from international theory to local practice. In two empirical chapters that follow, Blaustein demonstrates how UNDP and SDC have the power to bend and redesign the global policy practices in a local and national setting. Policy is not designed exclusively in Geneva or New York, but is co-produced in Sarajevo. Methodologically, Blaustein demonstrated the value of policy ethnography for global public policy research.

The book by Catherine Kingfisher titled "A Policy Travelogue: Tracing Welfare Reform in Aoteroa/New Zealand and Canada" is devoted to neo-liberal welfare reform. Unlike the previous book, the model of welfare support to single mothers has travelled to Canada not through transnational intermediaries, but high-ranked public servants and politicians. In order to make sense of this movement, the author employs two concepts, "policy translation" and "assemblages." Similarly to Blaustein, Kingfisher evokes policy translation in order to oppose the conventional approaches of "policy transfer" and "diffusion". However, unlike Blaustein, she focuses on how key policy actors morph the policy. Thus, "assemblages" help explain how actors work with the resources available to them to indigenize the policy model in their home conditions.

If Blaustein's work demonstrates the liberating power of translation to resist the global structures, for Kingfisher, translation is always bound by decision-rules and meta-norms, which are important to recognize if one is to design institutions. Methodologically, Kingfisher's work is a multi-sighted ethnography of the Prime Minister's office, welfare agency's offices, and perceptions of single mothers. As a result, Kingfisher paints a picture of two parallel forces of divergence and convergence in the work of policy translation in (a) creating and sustaining global hegemonies of neo-liberalism; and in (b) producing variegated forms of welfare policies on the ground. Most noteworthy, these processes seemingly take place without any involvement of transnational actors.

In the third book entitled "Fast Policy: Experimental Statecraft at the Thresholds of Neoliberalism," Jamie Peck and Nik Theodore further discuss neo-liberalism but place focus on transnational processes of policy design and diffusion. The focus of the book is not on what makes policies "transferable," but on the "social practices and infrastructures that enable and sustain policy "mobility" (Peck and Theodore, 2015: xviii). With two case studies, conditional cash transfers (CCT) and participatory budgeting (PB), the authors show how fast policy moves around the globe and becomes both pervasive and variegated. However, differently from the two books discussed above, the authors follow relatively well-articulated methodological guidelines they call "follow the policy". This is a significant methodological contribution, which suggests shadowing global policy consultants and experts as they conduct their work at the centers of power and in the periphery. The two cases provide interesting detail. The case study of CCT illustrates how Michael Bloomberg, then mayor of New York, aspired to learn from the Mexican experiences of poverty reduction through direct and intentional adaptation and experimentation with foreign models and experiences. In the second case study, the authors analyzed the birth of 
"participative budgeting," its packaging into a model by the World Bank and subsequent marketing around the world. Peck and Theodore made a significant departure from previous treatments of the subject in two ways, (a) they provide much empirical nuance and texture to their claims about the World Bank's role in making fast policy move, and (b) they introduce the conceptual apparatus to explain this process through such terms as "mutation," "modeling," and "transduction."

Finally, the fourth book is collaboratively penned by John Clarke, Dave Bainton, Noemi Lendvai, and Paul Stubbs and is titled "Making Policy Move: Towards a Politics of Translation and Assemblage." In this insightful volume, the topic of policy mobility receives a stylistic treat of "talking back" in dialogues between the authors. In chapter 1 and 2, authors lay the foundation for "policy translation" in viewing and analyzing public policy. In the rest of the book, individual authors provide their take on translation from different perspectives. In Chapter 3, Paul Stubbs discusses the welfare reform in the South East Europe. In Chapter 4, John Clarke takes another look at neo-liberalism, this time in restructuring a university. Noemi Lendvai's chapter discusses the fictions of the double reality of welfare policies in Hungary as practiced and as reported to the European Commission. Finally, Dave Bainton discusses what it means to translate western style education to remote areas in the global South.

The final chapter makes most of conceptual and methodological points of the book. One contribution is the ethics and politics of policy translation, an activity open not only to technocrats, but all policy actors. The authors evoke the idea of "policies otherwise" inspired by "development otherwise" (Rojas, 2007) and examine each case presented in the book through this lens. Another useful contribution is the call to study language in policy translation, as a mediator of power relations. Furthermore, Clarke et al. (2015) emphasize contingency of policy as the possibility for change. This argument resurfaces towards the end of the book and emphasized empowerment and emancipatory agenda in policy translation, very much in the spirit of Paolo Friere.

All four books share a number of key similarities. They take complexity seriously and acknowledge contingency in how policies move and unfold. This opens up space for viewing translation and the work of assemblages as creative activism in transcending the dominant power structures. Another key common theme is the central attention that the authors pay to how policies change, mutate and transform as they travel, taking up new lives and forms. All four volumes stressed multi-sighted ethnography, or "studying through," as a key methodology (Wright and Reinhold, 2011). Finally, the common thread in these works is the detailed, committed, and textured discussion of agents of policy translation at work, from the World Bank in Namibia, to individual consultants in Bosnia and Herzegovina.

However, upon reading these insightful books, a number of questions remain open. One is whether the transformation of polices as they travel is confined within some boundaries, and if so, how to discover such constraints in practice. Furthermore, with an exception of Clarke et al. (2005), the books have not dealt with the inherent ethical and political implications of engaging with the ethnography of policy translation. Cross-cultural research, integrity, and ethics are important conceptual and empirical issues for policy scholars, especially if more of ethnography is to be conducted. Methodologically and analytically, there is still much work to be done to study and engage in policy translation. The future work will hopefully refine the concepts, frameworks, and heuristics for that purpose. In conducting such work, a refreshed look at narratives, textuality, networks, and applied hermeneutics may be useful (e.g. Lejano and Park, 2015; Lejano et al., 2013).

These four books would be useful additions to the library of a policy scholar or a practitioner. They emphasize the emergence of the new vocabulary, conceptual tools and 
methodologies to study policy mobility. Furthermore, they show that the work of globalization and neo-liberalization is much more nuanced, textured, and complex than conventional theories may suggest (Mukhtarov, 2014). Finally, these books provide optimism that academic researchers and policy makers alike, through studying and doing policy translations, may enact change; however, deep-entrenched old institutions and power structures may seem.

\section{References}

Lejano R and Park SJ (2015) The aitopoietic text. In: Fischer F, Torgerson D, Durnova A, et al. (eds) Handbook of Critical Policy Studies. Cheltenham: Edward Elgar Publishing, Inc., pp. 274-297.

Lejano R, Ingram M and Ingram H (2013) The Power of Narrative in Environmental Networks. Cambridge: MIT Press.

Maybin J (2014) Policy analysis and policy know-how: A case study of civil servants in England's department of health. Journal of Comparative Policy Analysis: Research and Practice 17(3): 286-304.

Mukhtarov F (2014) Rethinking the travel of ideas: Policy translation in the water sector. Policy \& Politics 42(1): 71-88.

Pachirat T (2009) The Political in political ethnography: Dispatches from the kill floor. In: Schatz E (ed.) Political Ethnography: What Immersion Contributes to the Study of Power. Chicago: Chicago University Press, pp. 143-163.

Pratt M (1992) Imperial Eyes: Travel Writing and Transculturation. Abingdon: Taylor and Francis.

Rojas C (2007) International Political Economy/Development Otherwise. Globalizations 4(4): 573-587.

Stone D (2012) Transfer and translation of policy. Policy Studies 33(6): 483-499.

Wright S and Reinhold S (2011) "Studying through": A strategy for studying political transformations. Or sex, lies and British politics. In: Shore C, Wright S and Pero D (eds) Policy Worlds: Anthropology and the Analysis of Contemporary Power. Oxford: Berghahn Press, pp. 86-105. 